\title{
Analysis of Cytosine Methylation Pattern in Response to Water Deficit in Pea Root Tips
}

\author{
M. Labra ${ }^{1}$, A. Ghiani ${ }^{2}$, S. Citterio ${ }^{1}$, S. Sgorbati ${ }^{1}$, F. Sala ${ }^{2}$, C. Vannini ${ }^{3}$, M. Ruffini-Castiglione ${ }^{4}$, and M. Bracale ${ }^{3}$ \\ 1 Dipartimento di Scienze dell'Ambiente e del Territorio Universita' degli Studi di Milano-Bicocca, Milano, Italy \\ ${ }^{2}$ Dipartimento di Biologia, Università di Milano, Via Celoria 26, 20133 Milano, Italy \\ ${ }^{3}$ DBSF, Università dell' Insubria, Via J. H. Dunant 3, 21100 Varese, Italy \\ ${ }^{4}$ Istituto di Mutagenesi e Differenziamento, CNR Area della Ricerca, Via Moruzzi, 56124 Pisa, Italy
}

Received: June 3, 2002; Accepted: October 2, 2002

\begin{abstract}
The correlation between environmental stress and DNA methylation has been studied by following the methylation status of cytosine residues in the DNA of pea root tips exposed to water deficit. DNA methylation was evaluated by two complementary approaches: (i) immunolabelling by means of a monoclonal antibody against 5-methylcytosine; (ii) MSAP (Methylation-Sensitive Amplified Polymorphism) to verify if methylation and de-methylation in response to water deficit may be related to specific DNA sequences. Immunolabelling showed that water stress induces cytosine hypermethylation in the pea genome. Regarding the CCGG target sequence, an increase in methylation specifically in the second cytosine (about $40 \%$ of total site investigated) was revealed by MSAP analyses. In addition, MSAP band profile detected in three independent repetitions was highly reproducible suggesting that, at least for the CCGG target sequence, methylation was addressed to specific DNA sequences.
\end{abstract}

Key words: Pisum sativum L., DNA methylation, water stress, MSAP.

\section{Indroduction}

The expression of the information contained in the primary DNA sequence can be affected by the addition (or loss) of a methyl group to the ring structure of a cytosine residue. The epigenetic modification, which is mediated by methyl transferases enzymes, alters DNA-protein interaction and prevents cleavage by methylation-sensitive restriction endonucleases (Jost and Saluz, 1993 ${ }^{[15]}$ ). In animals, as in plants, the main consequence of methylation is interference with DNA transcription and replication. Effects on the extent of DNA mutation and on chromatin structure change have also been verified (Ehrlich and Ehrlich, 1993[9]). In human DNA, changes in methylation patterns are recognized as an agent for some diseases (Reik et al., 2001[26]; Bird, 2002[2]).

Plant genomes are methylated to a far greater extent than animal genomes: up to $40 \%$ of cytosine residues are methylated in plants, as compared with an average of $8 \%$ in animals (Adams

Plant biol. 4 (2002) 694-699

(c) Georg Thieme Verlag Stuttgart · New York ISSN 1435-8603 and Burdon, 1985[1]). Research to investigate the extent and role of methylation in plants has shown that: (i) methylation occurs predominantly on the cytosine residues in symmetrical sequences, such as CpG and CpNpG (Guenbaum et al., 1981 [12]; McClell, $1983^{[22]}$ ), (ii) DNA hyper- or hypomethylation is correlated with gene expression during development (Ulian et al., 1996[37]; Rossi et al., 1997[31]; Hoekenga et al., 2000[13]), and (iii) methylation plays an important role in the regulation of the activity of transposable elements (Martinessen and Richards, $1995^{[21]}$ ), in paramutation (Hollick et al., 1997[14]; Walker, $1998^{[39]}$ ) and in somaclonal variation induced by stress conditions (Cecchini et al., 1992 [5]; Lo Schiavo et al., 1989[20]; Kaeppler et al., 2000[17]).

Hypermethylation of tobacco heterochromatic loci in response to osmotic stress (Kovarik et al., 1997 ${ }^{[18]}$ ) and in silenced genes in transgenic plants (Meyer et al., 1992 ${ }^{[24]}$ ) has been reported; similarly, hypomethylation has been documented in chicory root tips (Demeulemeester et al., 1999 ${ }^{[7]}$ ) and in Arabidopsis thaliana L. (Finnegan et al., 1996 ${ }^{[9]}$ ) when exposed to low temperature. These findings support the hypothesis that variations in genome methylation are due to plant mechanisms for adaptation to abiotic stresses (Kovarik et al., 1997[18]) and make the investigation of the methylation status a relevant topic in the search for crop improvement.

Water availability is the major limiting factor to plant growth in many environments. In the present work, global changes in DNA methylation in water-stressed pea root tips were determined by immunolabelling with a monoclonal antibody against 5-methylcytosine and the Methylation-Sensitive Amplified Polymorphism (MSAP) technique (Reyna-Lòpez et al., $1997^{[27]}$ ) was used to correlate stress events to epigenetic changes. The results indicate that: $i$ ) DNA hypermethylation in pea root tips is induced by water deficiency; and ii) this hypermethylation at the CCGG sequences occurs in specific DNA sequences.

\section{Materials and Methods}

\section{Plant material and seedling treatment}

Pea (Pisum sativum L. cv. Alaska) seeds were surface sterilised in $10 \% \mathrm{NaClO}$ and germinated in moistened agriperlite at $25^{\circ} \mathrm{C}$ in the dark. After $72 \mathrm{~h}$, the seedlings were transferred to glass dissectors on top of $25 \% \mathrm{w} / \mathrm{v}$ glycerol (approx. $90 \%$ relative 
humidity) for 3 days in the dark. When pea seedlings are dried at $90 \%$ relative humidity for $72 \mathrm{~h}$, roots are able to resume growth quickly after being transferred to water (Bracale et al., $\left.1997^{[4]}\right)$.

Control seedlings were grown in agriperlite in the dark for the same period of time. One hundred seedlings and 100 root tips were weighed after 24,48 and $72 \mathrm{~h}$ of treatment to assess water loss. The relative water content was calculated as the per cent of weight of dehydrated apices versus control apices.

\section{DNA extraction}

Root tips ( $2 \mathrm{~mm}$ in length) were excised from seedling dehydrated for 24,48 and $72 \mathrm{~h}$ and from the corresponding control seedlings. At each time, 30 root tips were collected from both control and treated samples and immediately used for DNA extraction with the Plant tissue Kit (Quiagen). This procedure was repeated three times, using three independent control and treated samples.

\section{Slot-blot analysis}

DNA extracted from treated and control samples was used for slot-blot analysis. For each sample, $5 \mathrm{ng}$ of DNA were put on a nitocellulose filter, using the PR 600 Slot-Blot apparatus (Hoefer Scientific Instruments). The filter was incubated with a $1: 1000$ diluted mouse monoclonal antibody against 5-methylcytosine (anti-5-mC). The preparation and specificity of this monoclonal antibody have already been described (Podestà et al., $1993^{[25]}$ ) and were recently used to study DNA methylation dynamics in plants (Zluvova et al., 2001 ${ }^{[41]}$ ). After extensive washing, the filters were treated with a 1:9000 diluted antimouse alkaline phosphatase conjugated IgG. The secondary antibody was detected using 4-nitroblue tetrazolium chloride (Sigma). Image analysis was performed using the Gel Doc 2000 Image analysis system (Biorad).

DNA extraction and slot-blot analysis experiments were performed in triplicate.

\section{MSAP analysis}

DNA $(1 \mu \mathrm{g})$ was digested for $6 \mathrm{~h}$ at $37^{\circ} \mathrm{C}$ with $5 \mathrm{U}$ of EcoRI and $5 \mathrm{U}$ of Msp I (New England BioLabs) or $5 \mathrm{U}$ of Hpa II (New England BioLabs) in a final volume of $40 \mu$ l containing RL buffer (Gibco-BRL). DNA fragments were ligated (with 1 unit of T4 DNA ligase for $3 \mathrm{~h}$ at $37^{\circ} \mathrm{C}$ ) to the MspI-HpaII adapter ( $5 \mathrm{pmol}$ ) and EcoRI adapter $(0.5 \mathrm{pmol})$ in a final volume of $50 \mu \mathrm{l}$, as described (Xiong et al., 1999[39]).

Pre-amplification was performed in a mixture containing $5 \mu \mathrm{l}$ of the above mixture, $75 \mathrm{ng}$ of each $\mathrm{E}+01 / \mathrm{HM}+0$ primer (Table 1), $200 \mu \mathrm{M}$ of each dNTP, $0.5 \mathrm{U}$ of Dynazyme II (Finnzymes) and $5 \mu$ l of Dynazyme buffer (Finnzymes) in a final volume of $50 \mu \mathrm{l}$. After $2 \mathrm{~min}$ at $94^{\circ} \mathrm{C}$, pre-amplification was carried out for 20 cycles of denaturation ( $45 \mathrm{~s}$ at $94^{\circ} \mathrm{C}$ ), annealing ( $30 \mathrm{~s}$ at $50^{\circ} \mathrm{C}$ ) and extension $\left(1 \mathrm{~min}\right.$ at $72^{\circ} \mathrm{C}$ ). After a final elongation step ( $7 \mathrm{~min}$ at $72^{\circ} \mathrm{C}$ ) the pre-amplification product was diluted 1:50 with water and used for the selective amplification. This was carried out using one of the selective DNA primers (E32, E33, E34 and E37 of Table 1) complementary to the EcoRI adapter and one of the DNA primers (HM32, HM36,
Table 1 DNA primers for MAPS analysis

\begin{tabular}{ll}
\hline Name & DNA sequence \\
\hline HM+0 & 5'-ATCATGAGTCCTGCTCGG-3' \\
E+01 & 5'-GACTGCGTACCAATTC-3' \\
HM32 & 5'-ATCATGAGTCCTGCTCGGACA-3' \\
HM36 & 5'-ATCATGAGTCCTGCTCGGATT-3' \\
HM38 & 5'-ATCATGAGTCCTGCTCGGTCC-3' \\
HM39 & 5'-ATCATGAGTCCTGCTCGGAAT-3' \\
E32 & 5'-GACTGCGTACCAATTCTG \\
E33 & 5'-GACTGCGTACCAATTCAG \\
E34 & 5'-GACTGCGTACCAATTCAA \\
E37 & 5'-GACTGCGTACCAATTCCC \\
\hline
\end{tabular}

HM38, HM39 of Table 1) complementary to the MspI-HpaII adapter. The EcoRI primer was end-labelled with $\gamma^{33} \mathrm{P}-\mathrm{ATP}$ (Amersham, Italy). The amplification mixture ( $10 \mu \mathrm{l}$, final volume) contained $2.5 \mu$ l of the pre-amplification mixture, $3 \mathrm{ng}$ of labelled EcoRI primer, $15 \mathrm{ng}$ of MspI-HpaII primer, $200 \mu \mathrm{M}$ of each dNTP, $0.5 \mathrm{U}$ of Dynazyme II and $2 \mu \mathrm{l}$ of Dynazyme buffer. After $2 \mathrm{~min}$ at $94^{\circ} \mathrm{C}$ (denaturation), amplification was for 36 cycles under the following conditions: denaturation for $30 \mathrm{~s}$ at $94^{\circ} \mathrm{C}$; annealing for $30 \mathrm{~s}$ at $65^{\circ} \mathrm{C}$ in the first cycle, followed by a $0.7^{\circ} \mathrm{C}$ decrease in temperature in each of the next $12 \mathrm{cy}-$ cles, then at $56^{\circ} \mathrm{C}$ for the remaining 23 cycles; extension for $60 \mathrm{~s}$ at $72^{\circ} \mathrm{C}$. The PCR-amplified mixture $(1.5 \mu \mathrm{l})$ was added to an equal volume of loading buffer ( $80 \%$ formamide, $1 \mathrm{mg} \cdot \mathrm{ml}^{-1}$ xylene cyanol FF, $1 \mathrm{mg} \cdot \mathrm{ml}^{-1}$ bromophenol blue, $10 \mathrm{M}$ EDTA, $\mathrm{pH} 8.0$ ), denatured for $5 \mathrm{~min}$ at $92{ }^{\circ} \mathrm{C}$, loaded onto a $5 \%$ denaturing polyacrylamide gel and electrophoresed in TBE electrophoresis buffer for $3 \mathrm{~h}$ at 80 Watt. The gel was finally fixed in $10 \%$ acetic acid and exposed to an X-ray film for $24 \mathrm{~h}$. Polymorphic bands were scored by visual inspection of the resulting autoradiograms. Each band represents a recognition site cleaved by one or both of the isoschizomers. The methylation levels were deduced on the basis of DNA polymorphisms detected between the band patterns produced within each DNA preparation after digestion with two different enzymes (MspI and HpaII).

\section{Results}

\section{Seedling dehydration and slot-blot analysis}

Water content was determined in the whole seedling and in the root tip at 24,48 and $72 \mathrm{~h}$ after dehydration. Results were expressed as per cent of weight in the dehydrated samples versus the control. Weight, and thus water content, decreased considerably in seedlings grown in drought conditions, and was even further decreased in root tips, where, at time $72 \mathrm{~h}$ it was $55 \%$ of that of the controls (Fig. 1).

With the aim of quantifying DNA methylation variations, genomic DNA was extracted from dehydrated and control root tips, immobilized onto nitro-cellulose membranes and immunolabelled with the anti-5-mC. A representative example of the results obtained by this slot-blot analysis is shown in Fig. 2. After $24 \mathrm{~h}$ of dehydration, small differences between control and stressed samples was observed. After $48 \mathrm{~h}$ this difference became marked and after $72 \mathrm{~h}$ reached $63 \%$. This indicates an 


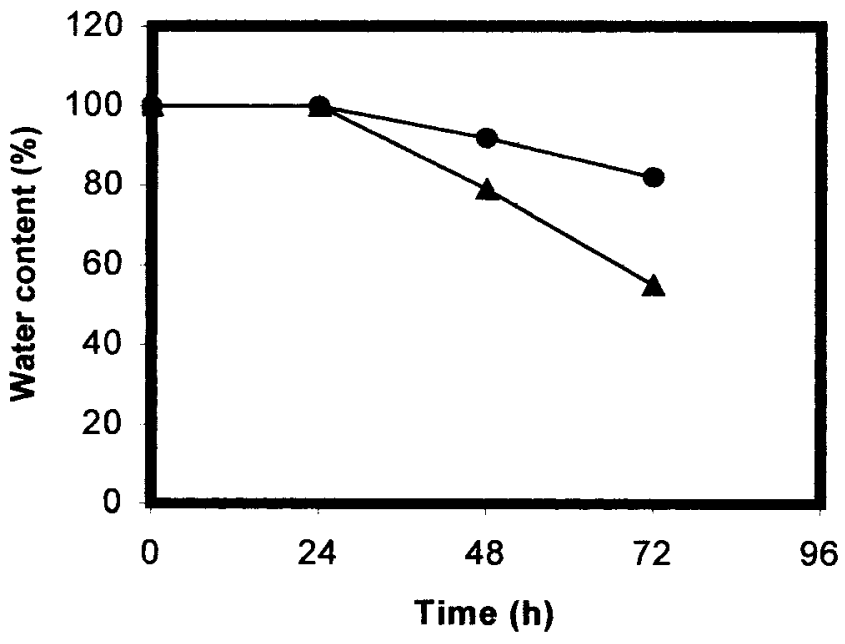

Fig. 1 Water content in pea seedling and root tips at different times after dehydration. Dehydration condition and analysis of water content were as described in Materials and Methods. $\bullet$ : seedling; $\boldsymbol{\Delta}$ : root tips.

extensive hypermethylation of cytosine residues in water stressed pea root tips. In the control lanes the amount of $5 \mathrm{mC}$ remains constant at the different times. This suggests that the DNA methylation level was not influenced by growth condition or plant development state.

\section{MSAP analysis}

MSAP analysis was performed to verify the information produced by slot-blot analysis and to establish whether DNA hypermethylation at the CCGG sequence in response to water deficit occurs at random within the genome or is addressed to specific DNA sequences.

Many MSAP primer combinations (Table 1), with two or three selective nucleotides at the EcoRI end and one to three selective nucleotides at the HpaII-MspI end were tested for their

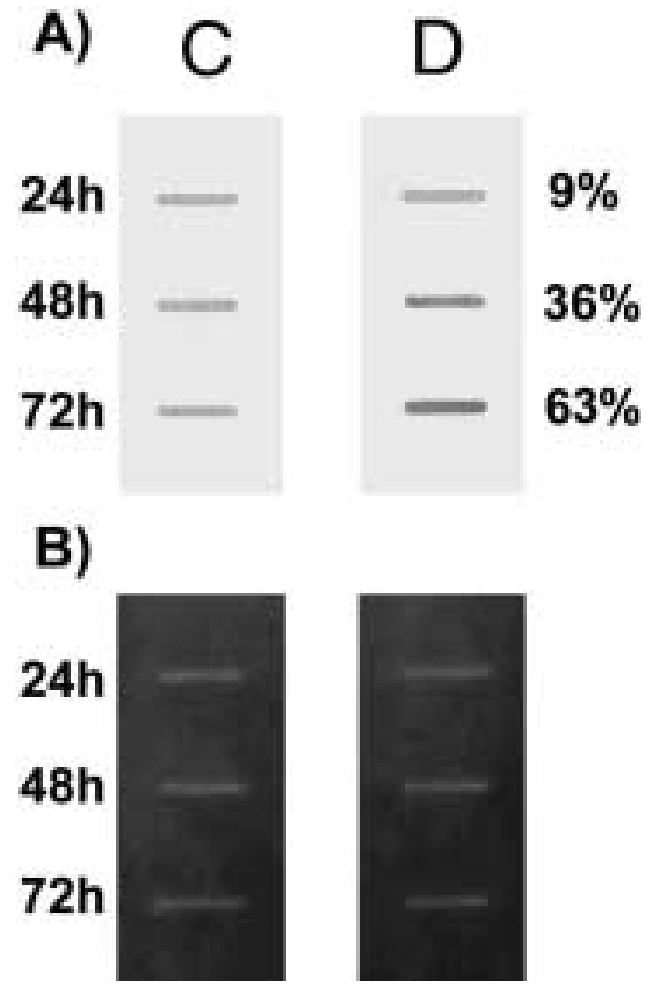

Fig. 2 (A) Slot-blot analysis of DNA from control (C) and dehydrated (D) root tips at different times after dehydration. Per cent refers to the increase in band intensity in the DNA from dehydrated root tips as compared with DNA from the control sample. Value was calculated by Image Analysis System Gel DOC 2000 Biorad. (B) DAPI-stained filters loaded with the same quantity of DNA as in $\mathbf{A}$ to check the amount of DNA loaded in each well.

ability to produce distinct scorable bands on the analysis gel. Of these, 10 DNA primer combinations (Table 2 ) were finally selected and used. For each combination, the number of bands visible on the gels varied from 45 to 68. Fig. 3 shows a repre-

Table 2 Number of amplified bands and methylation or hemi-methylation in CCGG site detected by each DNA primer pair. Total band detected in EcoRI-Mspl digestion lane. Number of full methylation sites or methylation in first cytosine were deduced by comparison pattern of EcoRI-Mspl digestion lane detected in dehydrated pea root tips versus control. Methylation in second cytosine was assessed by calculating number of fragments in the amplification product of EcoRI-Mspl lane absent in EcoRI-Hpall lane. Finally, hemi-methylated site was indicated as the band present in EcoRI-Hpall lane but not in EcoRI-Mspl, because Hpall digests hemimethylated sites while Mspl does not

\begin{tabular}{|c|c|c|c|c|c|c|}
\hline \multirow[t]{2}{*}{ Primer pair } & \multicolumn{3}{|c|}{ Control root tips } & \multicolumn{3}{|c|}{ Dehydrated root tips } \\
\hline & Total band & $\begin{array}{l}\text { Methylation in } \\
\text { second cytosine }\end{array}$ & $\begin{array}{l}\text { Hemimethyl- } \\
\text { ated sites }\end{array}$ & Total band & $\begin{array}{l}\text { Methylation in } \\
\text { second cytosine }\end{array}$ & $\begin{array}{l}\text { Hemimethyl- } \\
\text { ated sites }\end{array}$ \\
\hline HM32/E32 & 59 & 17 & 2 & 58 & 25 & 3 \\
\hline HM32/E33 & 64 & 11 & 2 & 60 & 21 & 2 \\
\hline HM36/E32 & 39 & 11 & 0 & 38 & 19 & 0 \\
\hline HM36/E33 & 55 & 18 & 4 & 55 & 27 & 4 \\
\hline HM36/E34 & 66 & 13 & 3 & 60 & 19 & 4 \\
\hline HM38/E32 & 57 & 11 & 0 & 57 & 22 & 0 \\
\hline HM38/E34 & 45 & 10 & 1 & 45 & 15 & 0 \\
\hline HM38/E37 & 57 & 13 & 0 & 53 & 25 & 0 \\
\hline HM39/E34 & 68 & 12 & 2 & 66 & 29 & 2 \\
\hline HM39/E37 & 61 & 13 & 0 & 61 & 24 & 0 \\
\hline TOT & 571 & 139 & 14 & 553 & 226 & 15 \\
\hline
\end{tabular}


sentative MAPS analysis with one of the selected primer combinations.

The stress experiments were repeated three times. The banding patterns produced were always clear and reproducible; i.e., $95 \%$ of bands with both enzymes were identical. These MSAP bands were rigorous reproducibility in control and dehydrated samples, indicating direct methylation activity addressed to specific DNA sequences.

The MSAP approach was based on different methylation sensitivity of two enzymes HpaII and MspI. Hpall digests only unmethylated CCGG sites or hemi-methylated sites (only one DNA strand methylated) but not sites that have either of the two cytosines methylated, while MspI digests CCGG and CmCCG sites but not mCCGG or mCmCGG sites (McClelland et al., 1994[23]).

Due to the differential DNA cleavage properties of these enzymes, different DNA fragment profiles were observed in control and dehydrated samples. In particular, using the 10 primer pairs selected, a total of 571 scorable bands were obtained from the control sample EcoRI - MspI digest and 553 bands from dehydrated EcoRI - MspI digest. On the other hand, in the EcoRI + HpaII digests of DNA from control and dehydrated root tips, a total of 139 and 226 bands, respectively, were absent (Table $\mathbf{2}$ ).

The results demonstrate that, during growth in normal conditions, a portion of the DNA is methylated in the second cytosine of the CCGG sequence (about 25\% of the total site investigated) and that this portion shows an increase to $40 \%$ in the site investigated in dehydrated root tips. This increase is due to methylation in specific DNA sequences, as assessed by the change in band pattern of the MSAP analysis observed in the different samples. On the other hand, methylation in the first cytosine and hemi-methylation do not change and are not substantially influenced by water stress, as shown in Table 2.

\section{Discussion}

The results of the slot-blot and MSAP analysis performed in this work show extensive hypermethylation of cytosine residues in water-stressed pea root tips. This is in agreement with data on DNA hypermethylation of tobacco and potato cell cultures in response to osmotic stress (Sabbah et al., 1995 ${ }^{\text {[32]; }}$ Kovarik et al., $1997^{[18]}$ ). In pea, an increase of methylation of both internal and external cytosine on the CCG sequence was detected in regenerated plants. Finally, in maize DNA methylation/demethylation was described in response to environmental stress (Steward et al., 2002 ${ }^{[35]}$ ). These data suggested that epigenetic change at the DNA methylation level might play an important role in plant adaptation to several forms of stress. In this work, we show that the same is true for plant response to stress induced by water deficit.

Bracale et al. (1997 $\left.{ }^{[4]}\right)$ described an arrest of the cell cycle in pea root tips under similar water stress conditions to those which induced hypermethylation in our experiments. This fact allowed us to postulate the existence of a connection between drought stress, cell division and DNA methylation. A relationship between water stress and reduction of plant development has been demonstrated in Arabidopsis thaliana and wheat (Ric-

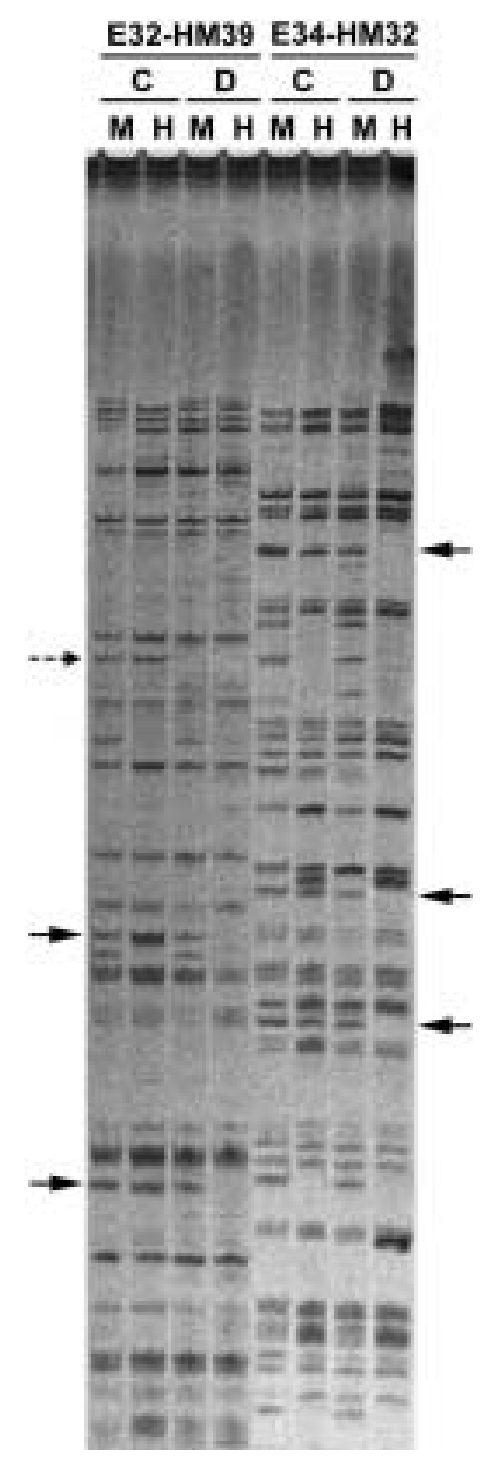

Fig. 3 Examples of methylation pattern detected from comparing DNA from control (C) and dehydrated (D) root tips, using two primer combinations: HM32-E32 and HM39-E34. H and M refer to digestion DNA with EcoRI-Hpall and EcoRl-Mspl, respectively. $\rightarrow$ : Hypermethylation in the second cytosine induced by water stress; - - $\rightarrow$ : Hypermethylation in both cytosines induced by water stress.

cardi et al., 1998 $\left.{ }^{[28]}\right)$. In the same stress conditions, a decrease in mitotic activity in meristematic cells has been reported in maize and sunflower (Robertson et al., 1990 ${ }^{[29]}$; Silk 1992 [34]; Sacks et al., $1997^{[33]}$ ). This, and the results of our experiment point to the conclusion that DNA methylation represents a powerful tool for the cell within a morphogenetic programme, depending on external or internal factors. It could be considered an example of cell potentiality and an important mechanism correlated to plant growth and development in response to biotic and abiotic environmental stresses.

The molecular mechanism by which methylation and demethylation take place in specific DNA target sequences involved in plant growth and development is not yet clear. DNA methylation changes could be directed to specific sequences or 
could be a random response to stress (Kaeppler and Phillips, $1993^{[16]}$ ); they could be the primary cause of gene inactivation or a secondary consequence of some other process that has resulted in transcriptional inactivation (Finnegan et al., 1998 ${ }^{[10]}$; Cocciolone et al., 1993 ${ }^{[6]}$ ). In animal systems, methylated cytosine can serve as a substrate for methyl-CpG-binding proteins. Some of these proteins are found as complexes with histone deacetylases and function as key components of the remodelling machinery responsible for chromatin condensation (Bird and Wolffe, $1999^{[3]}$ ). In this case, it is the variation in chromatin structure and not the direct methylation change of specific sequences that leads to changes: (i) in gene expression, (ii) in recombination rates and (iii) in the timing of DNA replication, perhaps causing chromosome breakage (Kaeppler and Phillips, $\left.1993^{[16]}\right)$. On the other hand, many papers have reported that, in both animals and plants, some genes are specifically silenced or activated by methylation (Furner et al., 1998 ${ }^{111}$; Steward et al., 2000 ${ }^{[36]}$ ).

A powerful tool for ascertaining whether methylation in response to water stress is directed to specific DNA sequences is the recently developed MSAP technique (Reyna-Lopez et al., $\left.1997^{[27]}\right)$. It is a modification of the Amplified Fragment Length Polymorphism (AFLP; Vos et al., 1995[38]) approach set up for the detection of 5'-methylcytosine in fungal DNA. This technique is a powerful tool to discover specific CCGG target sequences of methyltransferase enzymes.

In our study, MSAP served to indicate the methylation mechanism involved in normal and water stressed plant development. MSAP rigorous reproducibility in control and in stressed samples demonstrated direct methylation/demethylation activity addressed to specific DNA sequences. On the basis of this greater reproducibility of MSAP results, it is reasonable to propose a primary and direct role of hypermethylation in reducing the metabolic cell activity assessed by Bracale et al. $\left(1997^{[4]}\right)$ in pea root tip after $72 \mathrm{~h}$ of water stress. The epigenetic control of expression of specific genes by methylation mechanisms is supported by the recent identification of several class of methyltransferase (Finnegan et al., 1996 ${ }^{[9]}$; Ronemus et al., $1996^{[30]}$ ) directed to specific functional and structural genes characterized by $\mathrm{CpXpG}$ or $\mathrm{CpG}$ sequences and involved in the maintenance of this methylation (Lindroth et al., 2001 ${ }^{[19]}$ ). Recently, a study suggested a model where different loci may depend preferentially or either $\mathrm{CpGpC}$ or $\mathrm{CpG}$ methylation as the main mechanism of gene silencing and gene expression (Lindroth et al., 2001 ${ }^{[19]}$ ). Our understanding of the relationship between DNA methylation and transcriptional control is growing fast, but is still far from complete. Ongoing molecular and biochemical analysis of the growing number of components of the DNA methylation system will strengthen the link between DNA methylation and mainstream transcriptional mechanisms. Regulation of gene expression is complex and the emerging evidence hints that the roles of DNA methylation will be too. We consider that MSAP analysis provides the possibility of identifying the DNA sequences methylated during normal plant development and in response to environmental stresses. The characterization of these sequences and the study of their gene expression will clarify which type of genes were regulated by methyltransferase enzymes and the relationship between DNA methylation and gene expression or silencing.

\section{Acknowledgements}

We would like to thank Antonio Grippo for help in preparing photographs.

\section{References}

${ }^{1}$ Adams, R. L. P. and Burdon, R. H. (1985) Molecular Biology of Methylation. New York: Spinger-Verlag.

2 Bird, A. (2002) DNA methylation patterns and ephigenetic memory. Genes \& Development 16, 6-21.

${ }^{3}$ Bird, A. P. and Wolffe, A. P. (1999) Methylation-induced repressionbelts, braces and chromatin. Cell 99, $451-454$.

${ }^{4}$ Bracale, M., Levi, M., Savini, C., Dicorato, W., and Galli, M. G. (1997) Water deficit in pea root tips: effect on the cell cycle and on the production of dehydrin-like protein. Annals of Botany 79, $593-$ 600.

${ }^{5}$ Cecchini, E., Natali, L., Cavallini, A., and Durante, M. (1992) DNA variations in regenerated plants of pea (Pisum sativum L.). Theoretical Applied Genetics 84, 874-879.

${ }^{6}$ Cocciolone, S. M. and Cone, K. C. (1993) Ph-Bh, an anthocyanin regulatory gene of maize that leads to variegated pigmentation. Genetics $135,575-588$.

${ }^{7}$ Demeulemeester, M. A. C., Van Stallen, N., and De Proft, M. P. (1999) Degree of DNA methylation in chicory (Cichorium intybus L.): influence of plant age and vernalization. Plant Science 142, $101-108$.

${ }^{8}$ Ehrlich, M. and Ehrlich, K. C. (1993) Effect of DNA methylation on the binding of vertebrate and plant proteins to DNA. In DNA methylation: molecular biology and biological significance (Jost, J. P. and Saluz, H. P., eds.), New York: Springer-Verlag.

${ }^{9}$ Finnegan, E. J., Peacock, W. J., and Dennis, E. S. (1996) Reduced DNA methylation in Arabidopsis thaliana results in abnormal plant development. Proceeding of the Natural Academy of Science U.S.A. 93, 8449-8454.

${ }^{10}$ Finnegan, E. J., Genger, R. K., and Peacock, W. J. (1998) Dennis E.S. DNA methylation in plants. Annu. Rev. Plant Physiol. Plant Molecular Biology 49, $223-247$.

${ }^{11}$ Furner, I. J., Sheikh, M. A., and Collet, C. E. (1998) Gene silencing and homology-dependent gene silencing in Arabidopsis: genetic modifiers and DNA methylation. Genetics 149, 651 -662.

${ }^{12}$ Guenbaum, Y., Naveh-Many, T., Cedar, H., and Razin, A. (1981) Sequence specificity of methylation in higher plant DNA. Nature 292, $860-862$.

${ }^{13}$ Hoekenga, O. A., Muszynski, M. G., and Cone, K. C. (2000) Developmental pattern of chromatin structure and DNA methylation responsible for epigenetic expression of maize regulatory gene. Genetics 155, 1889-1902.

${ }^{14}$ Hollick, J. B., Dorweiller, J. E., and Chandler, V. I. (1997) Paramutation and related allelic interation. Trend Genetic 8, 302-307.

15 Jost, J. P. and Saluz, H. P., eds. (1993) DNA methylation: molecular biology and biological significance. New York: Springer-Verlag.

${ }^{16}$ Kaeppler, S. M. and Phillips, R. L. (1993) Tissue culture-induced DNA vmethylation variation in maize. Proceedings of the National Academy of Science USA 90, 8773-8776.

17 Kaeppler, S. M., Kaeppler, H. F., and Rhee, Y. (2000) Epigenetic aspects of somaclonal variation in plants. Plant Molecular Biology 43, $179-188$.

${ }^{18}$ Kovarik, A., Koukalovà, B., Bezdèk, M., and Opatrny, Z. (1997) Hypermethylation of tobacco heterochromatic loci in response to osmotic stress. Theoretical and Applied Genetics 95, $301-306$.

${ }^{19}$ Lindroth, A. M., Cao, X., Jackson, J. P., Zilberman, D., McCallum, C. M., Heinikoff, S., and Jacobsen, E. (2001) Requirement of chromomethylase3 for maintenance of $\mathrm{CpXpG}$ methylation. Science 292, 2077-2080. 
${ }^{20}$ Lo Schiavo, P., Pitto, L., Giuliano, G., Torti, G., Nuti-Ronchi, V., Marezzati, D., Vergera, R., Orselli, S., and Terzi, M. (1989) DNA methylation of embriogenic carrot cell culture and its variation as caused by mutation, differentiation, hormones and hypomethylation drugs. Theoretical and Applied Genetics 77, 325-331.

${ }^{21}$ Martinessen, R. A. and Richards, E. J. (1995) DNA Methylation in eukaryotes. Current Opinion in Genetics \& Development 5, 234242.

22 McClell, M. (1983) The frequency and distribution of methylation DNA sequences in leguminous plant protein coding genes. Journal of Molecular Evolution 19, 346-354.

${ }^{23}$ McClelland, M., Nelson, M., and Raschke, E. (1994) Effect of sitespecific modification on restriction endonucleases and DNA modification methyltransferases. Nucleic Acids Research 22, 36403659.

${ }^{24}$ Meyer, P., Linn, F., Heidmann, I., Meyer, A. H., Niedenhof, I., and Saedler, H. (1992) Endogenous and environmental factor influence $35 \mathrm{~S}$ promoter methylation of a maize A1 gene construct in transgenic petunia and its colour phenotype. Molecular General Genetics 231, 345-352.

25 Podestà, A., Ruffini-Castiglione, M., Avanzi, S., and Montagnoli, G. (1993) Molecular geometry of antigen binding by a monoclonal antibody against 5-methylcytosine. Int. J. Biochem. 25, 926- 933.

${ }^{26}$ Reik, W., Dean, W., and Walter, J. (2001) Epigenetic reprogramming in mammalian development. Science 293, 1089- 1093.

${ }^{27}$ Reyna-Lòpez, G. E., Simpson, J., and Ruiz-Herrera, J. (1997) Differences in DNA methylation patterns are detectable during the dimorphic transition of fungi by amplification of restriction polymorphisms. Molecular General Genetics 253, 703-710.

28 Riccardi, F., Gazeau, P., De Vienne, D., and Zivy, M. (1998) Protein changes in response to progressive water deficit in maize. Plant Physiology 117, $1253-1263$.

${ }^{29}$ Robertson, J. M., Hubick, K. T., Yeung, E. C., and Reid, D. M. (1990) Developmental responses to drought and abscisic acid in sunflower roots. 1. Root growth, apical anatomy, and osmotic adjustment. Journal of Experimental Botany 41, 325-337.

${ }^{30}$ Ronemus, M. J., Galbiati, M., Ticknor, C., Chen, J., and Dellaporta, S. L. (1996) Demethylation-induced developmental pleiotropy in Arabidopsis. Science 273, 654-656.

${ }^{31}$ Rossi, V., Motta, M., and Pellegrini, L. (1997) Analyses of the methylation pattern of the maize Opaque-2 (02) promoter and in vitro binding studies indicate that the $\mathrm{O} 2 \mathrm{~B}$-Zip protein and others endosperm factors can bind to methylation target sequences. Journal of Biological Chemistry 272, 13758-13765.

32 Sabbah, S., Raise, M., and Tal, M. (1995) Methylation of DNA in $\mathrm{NaCl}$-adapted cells of potato. Plant Cell Report 14, 467-470.

${ }^{33}$ Sacks, M. M., Silk, W. K., and Burman, P. (1997) Effect of water stress on cortical cell division rates within the apical meristem of primary roots of maize. Plant Physiology 114, 519-527.

${ }^{34}$ Silk, W. K. (1992) Steady from changing cell. International Journal of Plant Science 153, S49-S58.

${ }^{35}$ Steward, N., Ito, M., Yamaguchi, Y., Koizumi, N., and Sano, H. (2002) Periodic DNA methylation in maize nucleosomes and demethylation by environmental stress. Journal of Biological Chemistry 277, $37741-37746$.

${ }^{36}$ Steward, N., Kusano, T., and Sano, H. (2000) Expression of ZmMET1, a gene encoding a DNA methyltransferase from maize, is associated not only with DNA replication in actively proliferating cells but also with altered DNA methylation status in cold stress quiescent cell. Nucleic Acids Research 28, 3250-3259.

${ }^{37}$ Ulian, E. C., Magill, J. M., Magill, C. W., and Smith, R H. (1996) DNA methylation and expression of NPTII in transgenic petunians and progeny. Theoretical Applied Genetic 92, 976-981.

38 Vos, P., Hogers, R., Bleeker, M., Reijans, M., Lee, T., Hornes, M., Frijters, A., Pot, J., Peleman, J., Kuiper, M., and Zabeau, M. (1995) AFLP: a new technique for DNA fingerprinting. Nucleic Acids Research $23,4407-4414$.
${ }^{39}$ Walker, E. L. (1998) Paramutation of the $r 1$ locus of maize is associated with increased cytosine methylation. Genetics $148,1973-$ 1983.

${ }^{40}$ Xiong, L. Z., Xu, C. G., Saghai Maroof, M. A., and Quifa Zhang, M. A. (1999) Pattern of cytosine methylation in an elite rice hybrid and its parental lines, detected by a methylation-sensitive amplification polymorphism technique. Molecular General Genetics 261, 439-446.

${ }^{41}$ Zluvova, J., Janousek, B., and Vyskot, B. (2001) Immunohistochemical study of DNA methylation dynamics during plant development. Journal of Experimental Botany 52, 2265-2273.

\section{Labra}

Dipartimento di Scienze dell'Ambiente e del Territorio Università degli Studi di Milano-Bicocca

P.zza della Scienza n. 1

20126 Milano

Italy

E-mail: massimo.labra@unimib.it

Section Editor: F. Salamini 